Journal of Clinical Investigation

Vol. 41, No. 8, 1962

\title{
CONVERSION OF 17-HYDROXY-PREGNENOLONE TO CORTISOL BY NORMAL AND HYPERPLASTIC HUMAN ADRENAL SLICES *
}

\author{
By PATRICK J. MULROW, GEORGE L. COHN † AND ALBERT KULJIAN
}

(From the Medical Service, Veterans Administration Hospital, West Haven, and the Department of Medicine, Yale University School of Medicine, New Haven, Conn.)

(Submitted for publication February 14, 1962; accepted April 5, 1962)

Progesterone ${ }^{1}$ is a metabolic precursor common to cortisol and corticosterone biosynthesis in the adrenal cortex. However, incubation of radioactive progesterone with bovine adrenal homogenates (1) and human adrenal slices $(2,3)$ yields corticosterone with a specific activity greater than that of cortisol, even though the amount of cortisol produced is greater. Although hypotheses involving enzyme kinetics have been suggested to explain these results, other pathways of cortisol biosynthesis may exist that do not involve progesterone.

The pathway from progesterone to cortisol is believed to be via 17-hydroxyprogesterone $\rightarrow 11$ deoxycortisol $\rightarrow$ cortisol (4). Progesterone is derived from $\Delta^{5}$-pregnenolone upon oxidation of the $3 \beta$-hydroxyl group and a shift of the double bond. Hydroxylation of $\Delta^{5}$-pregnenolone to $17 \alpha$-hydroxy$\Delta^{5}$-pregnenolone is considered the first step in adrenal androgen biosynthesis (5). Conversion of 17-hydroxy- $\Delta^{5}$-pregnonolone to $17 \alpha$-hydroxy-progesterone by oxidation of the $3 \beta$-hydroxyl group and a shift of the double bond appeared to be a reasonable alternative possibility for cortisol biosynthesis. Indeed, Weliky and Engel (6) reported that 17 -hydroxy- $\Delta^{5}$-pregnenolone is metabolized to cortisol by sheep adrenal homogenates and by slices of a human adrenal tumor, and the present authors in preliminary reports have shown the conversion of $17 \alpha$-hydroxy- $\Delta^{5}$-pregnenolone- $7-\mathrm{H}^{3}$

\footnotetext{
* This work was supported by Grants C-3998 and A-254 (C8) from the U. S. Public Health Service.

† Advanced Research Fellow of the American Heart Association during part of this study.

${ }^{1}$ Compounds referred to are: progesterone (4-pregnene3,20-dione) ; cortisol (11 $\beta, 17 \alpha, 21$-trihydroxy-4-pregnene3,20-dione) ; corticosterone (11 $\beta, 21$-dihydroxy-4-pregnene3,20-dione) ; 11-deoxycortisol (17 $\alpha, 21$-dihydroxy-4-preg-

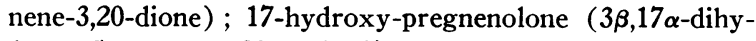
droxy-5-pregnene-20-one) ; $17 \alpha$-hydroxyprogesterone (17 $\alpha$ hydroxy-4-pregnene-3,20-dione); ACTH, adrenocorticotropic hormone.
}

to cortisol by slices of a hyperplastic human adrenal gland $(3,7)$.

The present report describes the conversion of 17-hydroxy- $\Delta^{5}$-pregnenolone to cortisol by slices of normal and hyperplastic human adrenal tissue. A pathway from 17-hydroxy- $\Delta^{5}$-pregnenolone $\rightarrow$ 17-hydroxyprogesterone $\rightarrow 11$-deoxycortisol $\rightarrow$ cortisol has been identified.

\section{MATERIALS AND METHODS}

All the adrenal glands were obtained by surgery and immediately iced until used. Adrenals were weighed, sectioned, freed of fat, reweighed, and sliced with a StadieRiggs microtome. Slices from different areas of each adrenal were taken for each experimental flask. Medullary tissue was not removed. Incubation of weighed slices was performed in a Dubnoff metabolic incubator for 3 hours at $37^{\circ} \mathrm{C}$ in $1 \mathrm{ml}$ of Krebs-Ringer bicarbonate buffer per $30 \mathrm{mg}$ of tissue with $200 \mathrm{mg}$ of glucose per 100 $\mathrm{ml}$ in an atmosphere of 95 per cent oxygen- 5 per cent $\mathrm{CO}_{2}$. The incubations were begun within 3 hours after excision of the adrenals.

The four normal adrenals were obtained from two patients with inoperable carcinoma of the prostate. $\mathrm{Pa}$ tient J.C. had had a bilateral orchiectomy and had received estrogenic therapy for 1 year prior to adrenalectomy. He received no glucocorticoid prior to the removal of the first adrenal. An infusion of $200 \mathrm{mg}$ cortisol-hemisuccinate was started and the second adrenal was removed. Patient M.K. underwent a bilateral orchiectomy and received estrogenic therapy for 2 years prior to adrenalectomy. Prednisone, $20 \mathrm{mg}$ each day, was administered for 3 months prior to adrenalectomy. During surgery, he received infusions of cortisol-hemisuccinate. The adrenals were of normal size.

Patient A.D., a 30-year-old female, had classical Cushing's syndrome. She received glucocorticoids on the day before and on the day of surgery. Two hyperplastic adrenals were found at surgery.

The substrate, $17 \alpha$-hydroxy- $\Delta^{5}$-pregnenolone- $7-\mathrm{H}^{3}$ (specific activity $2.6 \mathrm{mc}$ per $\mathrm{mg}$ ), was obtained from the New England Nuclear Corporation. It was subjected to three separate solvent partitionings (8) and then stored frozen in redistilled benezene : methanol $(9: 1$, vol/vol) until used. An aliquot was mixed with stable $17 \alpha$-hydroxy- $\Delta^{5}$-preg- 
nenolone and subjected to several different chromatography systems. A broad radioactive peak which corresponded to the broad peak of stable $17 \alpha$-hydroxy-pregnenolone was found. A second minor peak of radioactivity estimated to contain less than 5 per cent of radioactive $17 \alpha$-hydroxy-pregnenolone was noted in one system. The substrate progesterone-4-C $\mathrm{C}^{\mathbf{1 4}}$ was obtained from the New England Nuclear Corporation and subjected to two paper chromatographic systems prior to use.

In experiments $1,2,3$, and $4,17 \alpha$-hydroxy- $\Delta^{5}$-pregnenolone $-\mathrm{H}^{3}$ was added to the incubation flask either alone (experiments 1 and 2) or with stable $17 \alpha$-hydroxypregnenolone in ethanol:propylene glycol (experiments 3

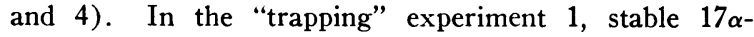
hydroxy-progesterone in ethanol:propylene glycol was also added prior to incubation. The volatile solvents were evaporated under nitrogen or air at $37^{\circ} \mathrm{C}$. In experiment 5 , approximately equimolar quantities of $17 \alpha$ hydroxy-pregnenolone-7- $\mathrm{H}^{3}$ and progesterone-4- $\mathrm{C}^{14}$ were added to each flask and dried under nitrogen. Propylene glycol, $0.1 \mathrm{ml}$, was added to facilitate solubilization of the substrates.

Separation and measurement of steroids. The media were extracted twice with $2 \mathrm{vol}$ of dichloromethane. The dichloromethane extract was washed once with 0.1 vol of $0.05 \mathrm{~N} \mathrm{NaOH}$, twice with 0.1 vol of distilled water, dried with anhydrous sodium sulfate, and evaporated in vacuum at $37^{\circ} \mathrm{C}$. The residues were applied to Whatman no. 1 chromatography paper and developed for approximately 72 hours in a modification of the toluene: propylene glycol system, i.e., propylene glycol was diluted with methanol $(1: 1 \mathrm{vol} / \mathrm{vol})$ before it was applied to paper and methanol was allowed to evaporate. The cortisol area was eluted with absolute ethanol and chromatographed successively in the Bush C system (9), then in the $\mathrm{E}_{2} \mathrm{~B}$ system (10). The effluents from the toluene: propylene glycol system were collected and chromatographed for 20 hours in the cyclohexane: dioxane: methanol: $\mathrm{H}_{2} \mathrm{O}$ system $(100: 100: 50: 25)$ (11) which separated corticosterone from 11-deoxycortisol. The effluents from the latter system were collected and after addition of carrier 17-hydroxyprogesterone to all except experiment 1 , chromatographed in the same system for 7 hours followed by the cyclohexane: benzene: methanol: water system $(100: 50: 100: 25)$ (11) for 8 hours.
Cortisol, 11-deoxycortisol, and corticosterone were acetylated with acetic anhydride: pyridine $(1: 1)$ and the monoacetate derivatives chromatographed in at least two systems. Hydrolysis of cortisol acetate was carried out with acetyl cholinesterase in glycylglycine buffer and the free alcohol extracted with methylene chloride. In experiments 1 through 4 , cortisol was oxidized with 2 per cent aqueous chromic acid for 18 hours at room temperature to adrenosterone which was isolated by paper chromatography in the cyclohexane: benzene: methanol: water system. Prior to chromic acid oxidation, authentic $\mathrm{C}^{14}$ cortisol was added. $\mathrm{H}^{3} / \mathrm{C}^{14}$ ratios were measured as the free cortisol and its adrenosterone derivative. In experiment 5 , cortisol underwent bismuth oxidation to $11 \beta$-hydroxyandrostenedione (12) which was isolated by paper chromatography in heptane : benzene : methanol: $\mathrm{H}_{2} \mathrm{O}$ (13) followed by a heptane: 96 per cent methanol system (13).

$17 \alpha$-Hydroxy-progesterone was oxidized with 2 per cent aqueous chromic acid for 20 hours at room temperature to $\Delta^{4}$-androstenedione. This derivative was isolated by chromatography in the heptane: 96 per cent methanol and the cyclohexane: benzene: methanol: water systems. Specific activities were measured by alkaline fluorescence (3) or ultraviolet absorption at 240 to $242 \mathrm{~m} \mu$ and by liquid scintillation counting.

\section{RESULTS}

The conversion of $17 \alpha$-hydroxy- $\Delta^{5}$-pregnenolone to cortisol by human adrenal slices is illustrated in Table I. The specific activity of cortisol was not measured until after it was subjected to three successive chromatography systems as the free alcohol (toluene: propylene glycol $\rightarrow$ Bush C $\left.\rightarrow \mathrm{E}_{2} \mathrm{~B}\right)$. Previous experience with cortisol- $\mathrm{H}^{3}$ derived from progesterone-16- $\mathrm{H}^{3}$ indicated that this was sufficient to insure radiochemical purity (3). Table II illustrates that this holds true for cortisol derived from $17 \alpha$-hydroxy- $\Delta^{5}$-pregnenolone-7- $\mathrm{H}^{3}$. The per cent conversion represented is a minimum, since no corrections were made for losses in the purification of cortisol. In our laboratory the losses involved in extractions and purifica-

TABLE I

Conversion of $17 \alpha$-hydroxy- $\Delta^{5}$-pregnenolone- $7-H^{3}$ to cortisol by human adrenal slices

\begin{tabular}{|c|c|c|c|c|c|c|c|c|c|}
\hline \multirow[b]{2}{*}{ Exp. } & \multirow[b]{2}{*}{$\mathrm{Pt}$} & \multirow[b]{2}{*}{ Pathology } & \multicolumn{2}{|c|}{ Tissue $\mathrm{Wt}$} & \multicolumn{2}{|c|}{ Substrate } & \multirow{2}{*}{\multicolumn{2}{|c|}{ Cortisol produced }} & \multirow{2}{*}{$\begin{array}{l}\text { Conver- } \\
\text { sion* }\end{array}$} \\
\hline & & & Total & Incubated & S.A. & Amt & & & \\
\hline & & & $g$ & $g$ & $\mu c / \mu$ mole & $\mu c$ & $\mu g / g / 3$ hrs & $\mu c / \mu m o l e$ & $\%$ \\
\hline 1 & J.C. & Normal, rt & 3.6 & 2.93 & $8.58 \times 10^{2}$ & $4.76 \dagger$ & $389 \dagger$ & $0.15 \dagger$ & $9.8 \dagger$ \\
\hline 2 & J.C. & Normal, it & 4.7 & 2.52 & $8.58 \times 10^{2}$ & 3.96 & 42.5 & 2.61 & 19.3 \\
\hline 3 & M. K. & Normal, rt & 8.7 & 4.94 & 1.19 & 2.86 & 53.5 & 0.32 & 8.2 \\
\hline 4 & M.K. & Normal, it & 7.0 & 4.00 & 1.19 & 2.86 & 67.2 & 0.33 & 8.8 \\
\hline
\end{tabular}

* Per cent conversion of the radioactivity of the substrate cortisol

$\dagger$ Approximately $3 \mathrm{mg}$ of stable $17 \alpha$-hydroxy-progesterone was added to the media prior to incubation. 
TABLE II

Radiochemical purity of cortisol- $H^{3}$ derived from $17 \alpha$-hydroxy- $\Delta^{5}$-pregnenolone-7- $H^{3}$

\begin{tabular}{|c|c|c|c|c|}
\hline $\begin{array}{c}\text { Chromatography } \\
\text { system * }\end{array}$ & $\begin{array}{l}\text { Exp. } 1 \\
\text { S.A. }\end{array}$ & $\begin{array}{l}\text { Exp. } 2 \\
\text { S.A. }\end{array}$ & $\begin{array}{l}\text { Exp. } 3 \\
\text { S.A. }\end{array}$ & $\begin{array}{l}\text { Exp. } 4 \\
\text { S.A. }\end{array}$ \\
\hline & \multicolumn{2}{|c|}{$\mu c / \mu m o l e$} & \multicolumn{2}{|c|}{$\mu c / \mu m o l e$} \\
\hline $\mathrm{E}_{2} \mathrm{~B}$ & 0.15 & 2.61 & 0.32 & 0.33 \\
\hline \multicolumn{5}{|c|}{$\begin{array}{c}\text { Carrier cortisol } \\
\downarrow \\
0.78\end{array}$} \\
\hline \multicolumn{5}{|c|}{ Acetylation to cortisol monoacetate } \\
\hline $\begin{array}{l}\text { Dioxane: } \\
\text { cyclohexane: } \\
\text { methanol: } \\
\mathrm{H}_{2} \mathrm{O}\end{array}$ & 0.15 & 0.83 & 0.34 & 0.36 \\
\hline $\begin{array}{l}\text { Benzene: } \\
\text { cyclohexane: } \\
\text { methanol: } \\
\mathrm{H}_{2} \mathrm{O}\end{array}$ & 0.16 & 0.84 & 0.29 & 0.29 \\
\hline \multicolumn{5}{|c|}{ Hydrolysis to cortisol } \\
\hline \multicolumn{5}{|c|}{ Addition of authentic $\mathrm{C}^{14}$-cortisol } \\
\hline $\mathrm{E}_{2} \mathrm{~B}$ & $\begin{array}{c}\mathrm{H}^{3} / \mathrm{C}^{14} \text { ratios } \\
8.64\end{array}$ & $\begin{array}{c}\mathrm{H}^{3} / \mathrm{C}^{14} \text { ratios } \\
17.2\end{array}$ & $\begin{array}{c}\mathrm{H}^{3} / \mathrm{C}^{14} \text { ratios } \\
12.0\end{array}$ & $\begin{array}{c}\mathrm{H}^{3} / \mathrm{C}^{14} \text { ratios } \\
12.5\end{array}$ \\
\hline \multicolumn{5}{|c|}{ Chromic acid oxidation to adrenosterone } \\
\hline $\begin{array}{l}\text { Benzene: } \\
\text { cyclohexane: } \\
\text { methanol: } \\
\mathrm{H}_{2} \mathrm{O}\end{array}$ & 7.95 & 15.4 & 11.3 & 11.1 \\
\hline
\end{tabular}
system.

* The cortisol was chromatographed in the toluene:propylene glycol and in the Bush C system prior to the $\mathrm{E}_{2} \mathrm{~B}$

tion of cortisol to this degree are from 30 to 50 per cent. As might be expected, addition of large quantities of stable $17 \alpha$-hydroxyprogesterone to the incubation media of experiment 1 led to a marked increase in cortisol production. Incubation, under similar conditions, of tissue from the left and right adrenals of the same patient (experiments 3 and 4 ) led to similar results.

TABLE III

Conversion of $17 \alpha$-hydroxy- $\Delta^{5}$-pregnenolone-7- $H^{3}$ to 11-deoxycortisol-7- $H^{3}$

\begin{tabular}{|c|c|c|c|c|c|c|c|c|}
\hline \multirow[t]{2}{*}{$\begin{array}{c}\text { Chromatography } \\
\text { system* }\end{array}$} & \multicolumn{2}{|c|}{ Exp. 1} & \multicolumn{2}{|c|}{ Exp. 2} & \multicolumn{2}{|c|}{ Exp. 3} & \multicolumn{2}{|c|}{ Exp. 4} \\
\hline & $\mu c / \mu m o l e$ & $\%$ conv. & $\underset{\mu m o l e}{\mu c /}$ & $\%$ conv. & $\mu c / \mu m o l e \dagger$ & $\%$ conv. & $\mu c / \mu m o l e \dagger$ & $\%$ conv \\
\hline $\begin{array}{l}\text { Dioxane: } \\
\text { cyclohexane: } \\
\text { methanol: } \\
\mathrm{H}_{2} \mathrm{O}\end{array}$ & 0.15 & 2.62 & 0.16 & 2.1 & 0.039 & 0.69 & 0.042 & 0.74 \\
\hline & \multicolumn{6}{|c|}{ Acetylation to 11-deoxycortisol monoacetate } & & \\
\hline $\begin{array}{l}\text { Dioxane: } \\
\text { cyclohexane: } \\
\text { methanol: } \\
\mathrm{H}_{2} \mathrm{O} \\
\text { Cyclohexane: } \\
\text { benzene: } \\
\text { methanol: } \\
\mathrm{H}_{2} \mathrm{O}\end{array}$ & 0.12 & & 0.14 & & 0.028 & & 0.028 & \\
\hline
\end{tabular}

* The 11-deoxycortisol was chromatographed in the toluene:propylene glycol, then in the dioxane:cyclohexane: methanol: $\mathrm{H}_{2} \mathrm{O}$ system prior to rechromatography in the latter system.

$\dagger$ Specific activities were measured after the addition of $150 \mu \mathrm{g}$ of carrier 11-deoxycortisol. 
TABLE IV

Conversion of $17 \alpha-h y d r o x y-\Delta^{5}-$ pregnenolone-7- $H^{3}$ to $17 \alpha$-hydroxy- $\Delta^{4}$-progesterone-7- $H^{3}$

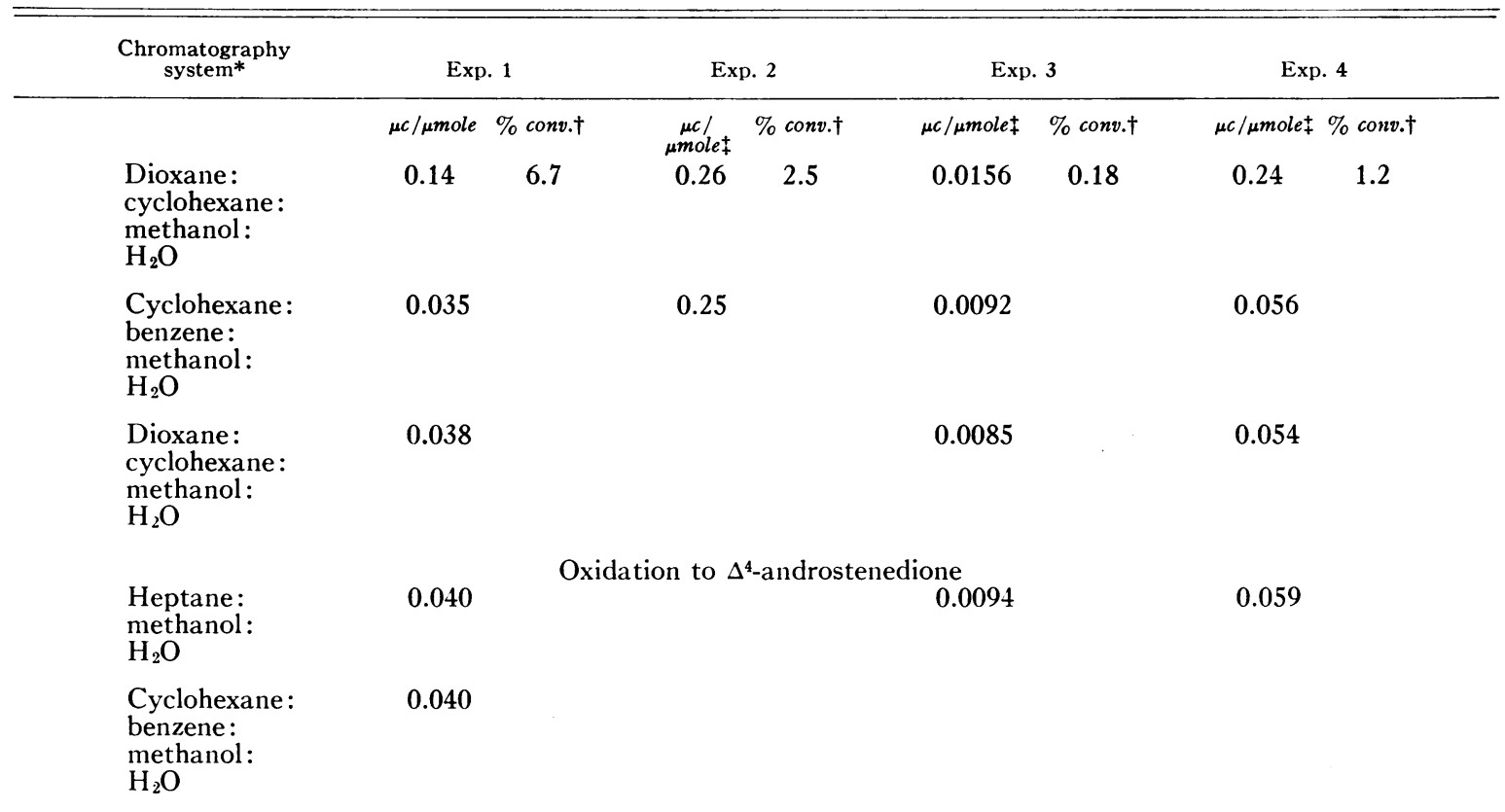

* The $17 \alpha$-hydroxyprogesterone was chromatographed in the toluene:propylene glycol, then in the cyclohexane: dioxane:methanol: $\mathrm{H}_{2} \mathrm{O}$ system prior to rechromatography in the latter system.

$\dagger$ The actual amount of radioactivity measured after the third chromatogram was corrected for the final specific activity.

$\ddagger$ Specific activities were measured after addition of carrier $17 \alpha$-hydroxyprogesterone.

Conversion to 11-deoxycortisol. In Table III, the results of conversion of $17 \alpha$-hydroxy- $\Delta^{5}$-pregnenolone-7- $\mathrm{H}^{3}$ to 11-deoxycortisol are shown. Since only a few micrograms of 11-deoxycortisol were produced by the adrenals, the specific activities were measured after the addition of approximately $150 \mu \mathrm{g}$ of carrier 11-deoxycortisol in experiments 2,3 , and 4 . In experiment 1 the addition of $17 \alpha$-hydroxy-progesterone increased the production of 11-deoxycortisol sufficiently so that addition of carrier was unnecessary. Adrenal tissue from the same patient (experiments 1 and 2, 3 and 4) incorporated approximately the same amount of radioactivity. Radiochemical purity was demonstrated after acetylation and chromatography in two systems.

Conversion to $17 \alpha$-hydroxyprogesterone. The results are shown in Table IV. Except in experi-

TABLE V

Incorportaion of $17 \alpha$-hydroxy- $\Delta^{5}$-pregnenolone-7- $H^{3}$ and progesterone-4-C $C^{14}$ to cortisol by hyperplastic human adrenal slices

\begin{tabular}{|c|c|c|c|c|c|c|c|c|c|c|}
\hline \multirow[b]{2}{*}{$\mathrm{Pt}$} & \multirow[b]{2}{*}{ Exp. } & \multirow{2}{*}{$\begin{array}{c}\text { Tissue } \\
\text { wt } \\
\text { incubated }\end{array}$} & \multicolumn{4}{|c|}{ Substrate } & \multicolumn{4}{|c|}{ Cortisol produced $*$} \\
\hline & & & Type mixturet & & & $\begin{array}{l}\text { Ratio } \\
\mathrm{H}^{3} / \mathrm{C}^{14}\end{array}$ & & S.A. & $\begin{array}{c}\% \\
\text { conv. }\end{array}$ & $\begin{array}{l}\text { Ratio } \\
\mathrm{H}^{3} / \mathrm{C}^{14}\end{array}$ \\
\hline & & & & $\mu g$ & $\mu c$ & & $\begin{array}{r}\mu g / g / \\
3 \text { hrs }\end{array}$ & $\mu \mathrm{c} / \mu \mathrm{mole}$ & & \\
\hline A.D. & Control & 2.433 & $\begin{array}{l}\text { 17-hydroxy-pregnenolone- } \mathrm{H}^{3} \\
\text { progesterone-C }\end{array}$ & $\begin{array}{l}406 \\
549\end{array}$ & $\begin{array}{l}5.67 \\
2.75\end{array}$ & 2.06 & 37.4 & $\begin{array}{l}1.34 \\
0.995\end{array}$ & $\begin{array}{l}5.9 \\
9.0\end{array}$ & 1.34 \\
\hline A.D. & АСТН§ & 1.946 & $\begin{array}{l}\text { 17-hydroxy-pregnenolone- } \mathrm{H}^{3} \\
\text { progesterone-C14 }\end{array}$ & $\begin{array}{l}325 \\
439\end{array}$ & $\begin{array}{l}4.54 \\
2.20\end{array}$ & 2.06 & 43.2 & $\begin{array}{l}0.840 \\
0.785\end{array}$ & $\begin{array}{l}4.1 \\
8.3\end{array}$ & 1.03 \\
\hline
\end{tabular}

* Measurements made after second chromatography system (Bush C).

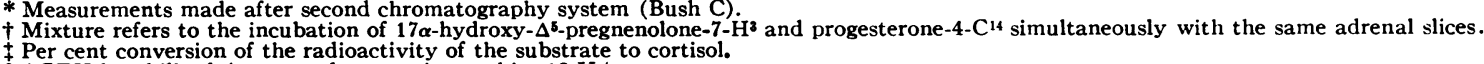


TABLE VI

Radiochemical purity of cortisol derived from $17 \alpha$-hydroxy- $\Delta^{5}$-pregnenolone-7- $H^{3}$ and progesterone-4- $C^{14}$

\begin{tabular}{|c|c|c|c|c|}
\hline \multirow{2}{*}{$\begin{array}{l}\text { Chromatography } \\
\text { system }\end{array}$} & \multirow[b]{2}{*}{ Exp. } & \multicolumn{2}{|c|}{ Specific activity } & \multirow[b]{2}{*}{ Ratio $\mathrm{H}^{3} / \mathrm{C}^{14} *$} \\
\hline & & $\mathrm{H}^{3}$ & $\mathrm{C}^{14}$ & \\
\hline $\mathrm{E}_{2} \mathrm{~B}$ & $\begin{array}{l}\text { Control } \\
\text { ACTH }\end{array}$ & $\begin{array}{c}\mu c / \mu M \text { ole } \\
1.14 \\
0.626\end{array}$ & $\begin{array}{c}\mu c / \mu \text { Mole } \\
0.866 \\
0.583\end{array}$ & $\begin{array}{l}1.30 \\
1.07\end{array}$ \\
\hline \multicolumn{5}{|c|}{ Acetylation to cortisol monoacetate } \\
\hline \multirow{5}{*}{$\begin{array}{l}\mathrm{CCl}_{4}: \\
\text { methanol: } \\
\mathrm{H}_{2} \mathrm{O} \\
\text { Dioxane: } \\
\text { cyclohexane: } \\
\text { methanol: } \\
\mathrm{H}_{2} \mathrm{O} \\
\text { Benzene: } \\
\text { cyclohexane: } \\
\text { methanol: } \\
\mathrm{H}_{2} \mathrm{O}\end{array}$} & Control & & & $1.47 \dagger$ \\
\hline & $\begin{array}{l}\text { ACTH } \\
\text { Control }\end{array}$ & 1.27 & 1.01 & $\begin{array}{l}1.05 \dagger \\
1.25\end{array}$ \\
\hline & $\mathrm{ACTH}$ & 0.695 & 0.536 & 1.03 \\
\hline & Control & 1.19 & 0.98 & 1.22 \\
\hline & ACTH & 0.80 & 0.572 & 1.11 \\
\hline $\mathrm{E}_{2} \mathrm{~B}$ & $\begin{array}{l}\text { Control } \\
\text { ACTH }\end{array}$ & to cortis & & $\begin{array}{l}1.27 \\
0.93\end{array}$ \\
\hline \multicolumn{5}{|c|}{ Bismuthate oxidation to $11 \beta$-hydroxy $-\Delta^{4}$ androstenedione $\ddagger$} \\
\hline $\begin{array}{l}\text { Ligroin: } \\
\text { benzene: } \\
\text { methanol: } \\
\mathrm{H}_{2} \mathrm{O} \\
\text { Heptane: } \\
\text { methanol: } \\
\mathrm{H}_{2} \mathrm{O}\end{array}$ & Control & & & $1.04 \dagger$ \\
\hline
\end{tabular}

* Ratio $\mathrm{H}^{3} / \mathrm{C}^{14}$ of substrate before incubation was 2.06 .

† Only a single aliquot was measured. All other measurements were done in triplicate.

$\ddagger$ Carrier cortisol, $50 \mu \mathrm{g}$, was added prior to oxidation.

ment 1 , where carrier $17 \boldsymbol{\alpha}$-hydroxyprogesterone was added to the media prior to incubation, no $17 \alpha$-hydroxyprogesterone was detected on the chromatograms by ultraviolet scanning. Specific activities were measured after the addition of carrier $17 \alpha$-hydroxyprogesterone. In 3 of 4 experiments radiochemical purity was demonstrated as the free alcohol, and after oxidation $\Delta^{4}$-androstenedione. The highest per cent incorporation of $17 \alpha$ hydroxy- $\Delta^{5}$-pregnenolone to $17 \alpha$-hydroxyprogesterone occurred in the "trapping" experiment 1.

Comparison of conversion of progesterone-4-C $C^{14}$ and $17 \alpha$-hydroxy-pregnenolone- $7-H^{3}$ to cortisol by slices of a hyperplastic gland. The results of the simultaneous incubation of equimolar concentrations of progesterone-4-C $\mathrm{C}^{14}$ and $17 \alpha$-hydroxy- $\Delta^{5}$ pregnenolone-7 $-\mathrm{H}^{3}$ with slices of a hyperplastic human adrenal gland obtained from patient with Cushing's syndrome are shown in Table V. The addition of ACTH in vitro did not sig- nificantly alter the production of cortisol or the conversion of the precursor. Slightly more progesterone was converted to cortisol than $17 \alpha$-hydroxy- $\Delta^{5}$-pregnenolone. Table VI demonstrates the radiochemical purity of the derived cortisol.

As was expected, little or none of the tritium in $17 \alpha$-hydroxy- $\Delta^{5}$-pregnenolone was converted to corticosterone. In experiment 2 the corrected per cent conversion was 0.09 , but in experiment 5 no tritium was detected in the corticosterone isolated from either the control or ACTH experiment.

\section{DISCUSSION}

The present experiments have demonstrated that $17 \alpha$-hydroxy- $\Delta^{5}$-pregnenolone- $7-\mathrm{H}^{3}$ is converted to cortisol by slices of normal and hyperplastic human adrenal glands. A pathway from $17 \alpha$-hydroxy- $\Delta^{5}$-pregnenolone through $17 \alpha$-hydroxy-progesterone $\rightarrow$ 11-deoxycortisol $\rightarrow$ cortisol has been identified (Figure 1). Other pathways, 
of course, have not been excluded. Welicky and Engel (6) have demonstrated that $17 \alpha$-hydroxy$\Delta^{5}$-pregnenolone is a major precursor for cortisol biosynthesis in sheep adrenals and in one human adrenal adenoma in vitro. In a preliminary communication, Lipsett and Hökfelt (14) reported that

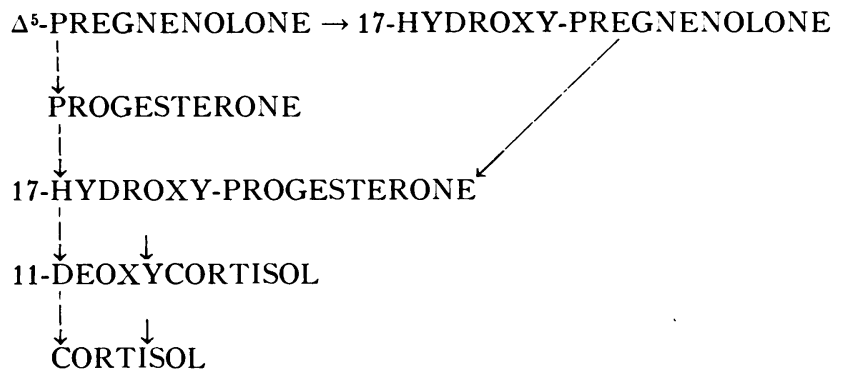

Fig. 1. Pathways of CORTISOL biosynthesis.

slices of human, guinea pig, and rat adrenals metabolized $17 \alpha$-hydroxy- $\Delta^{5}$-pregnenolone- $\mathrm{H}^{3}$ to cortisol via a pathway identical to one described in the present study. They found that 9 per cent of the labeled $17 \alpha$-hydroxy- $\Delta^{5}$-pregnenolone was converted to cortisol.

The extent of conversion of $17 \alpha$-hydroxy- $\Delta^{5}$ pregnenolone to cortisol in vitro compares favorably with the conversion of progesterone to cortisol. In a previous study (3), the present authors found that slices of a normal adrenal gland converted 6.8 per cent of tracer quantities of progesterone-16- $\mathrm{H}^{3}$, whereas slices of hyperplastic or adenomatous adrenal tissue converted 5.8 to 16.2 per cent. In experiment 5 of the present study, incubation of an equimolar concentration of $17 \alpha-$ hydroxy- $\Delta^{5}$-pregnenolone- $7-\mathrm{H}^{3}$ and progesterone4-C $\mathrm{C}^{14}$ with slices of a hyperplastic adrenal resulted in a greater per cent conversion of progesterone-4$\mathrm{C}^{14}$ than $17 \alpha$-hydroxy- $\Delta^{5}$-pregnenolone- $\mathrm{H}^{3}$. Weliky and Engel (6) in a similar type of experiment found that a human adrenal adenoma converted 50 per cent of $17 \alpha$-hydroxy- $\Delta^{5}$-pregnenolone and 15 per cent of progesterone- $\mathrm{C}^{14}$ to cortisol. This type of experiment is difficult to interpret, however, since the results may be influenced by many factors, such as rates of penetration of the two substrates into their enzyme sites, size of intracellular pools of intermediates in the respective pathways, and activity of the enzymes in vitro. Moreover, in vitro experiments may not reflect the biosynthetic events occurring in vivo. Since progesterone and $17 \alpha$-hydroxy- $\Delta^{5}$-pregnenolone are derived from a common precursor, pregnenolone, the relative importance of the two pathways of corti- sol biosynthesis depends upon: 1) the rates of conversion of pregnenolone to either progesterone or $17 \alpha$-hydroxy- $\Delta^{5}$-pregnenolone, and 2) their rates of conversion to 17-hydroxyprogesterone. The enzyme systems involved in the latter reactions would have to compete with the enzyme systems which metabolize progesterone and $17 \alpha$-hydroxy$\Delta^{5}$-pregnenolone to compounds other than 17-hydroxyprogesterone.

Nevertheless, since a pathway from $17 \alpha$-hydroxy- $\Delta^{5}$-pregnenolone to cortisol has been demonstrated to exist in vitro, it is a possibility that one reason for the lower specific activity of cortisol compared to corticosterone when radioactive progesterone is incubated with human adrenal tissue is the presence of an alternative pathway of cortisol synthesis. Production of cortisol by way of this alternative pathway might "dilute" the cortisol derived from radioactive progesterone.

\section{SUMMARY}

Conversion of $17 \alpha$-hydroxy- $\Delta^{5}$-pregnenolone-7$\mathrm{H}^{3}$ to cortisol by slices of four normal adrenals and one hyperplastic adrenal has been demonstrated. The slices of normal adrenal tissue converted from 9 to 19 per cent of the $17 \alpha$-hydroxy$\Delta^{5}$-pregnenolone-7- $\mathrm{H}^{3}$ to cortisol, whereas slices of the hyperplastic gland incorporated 5 per cent. A pathway from $17 \alpha$-hydroxy- $\Delta^{5}$-pregnenolone $\rightarrow$ $17 \alpha$-hydroxy-progesterone $\rightarrow 11$-deoxycortisol $\rightarrow$ cortisol has been identified.

\section{ACKNOWLEDGMENTS}

The authors wish to thank Mr. Walter Herniak, Miss Patricia Tomassi, and Miss Vera Dunne for their technical assistance. 


\section{REFERENCES}

1. Eichhorn, J., and Hechter, O. The unequal incorporation of tracer progesterone- $\mathrm{C}^{14}$ into corticosterone and cortisol synthesized by homogenates of bovine adrenal cortex. Arch. Biochem. 1959, 84, 196.

2. Berliner, M. L., Berliner, D. L., and Dougherty, T. F. Metabolism of progesterone by adrenal tissue from patients with Cushing's syndrome and mammary carcinoma. J. clin. Endocr. 1958, 18, 109.

3. Mulrow, P. J., and Cohn, G. L. Corticosteroid release and synthesis in vitro by adrenal slices from patients with Cushing's syndrome. J. clin. Invest. 1961, 40, 1250.

4. Hechter, O., and Pincus, G. Genesis of adrenocortical secretion. Physiol. Rev. 1954, 34, 459.

5. Lieberman, S., and Teich, S. Metabolic precursors of urinary dehydroisoandrosterone. J. clin. Endocr. 1953, 13, 1140.

6. Weliky, I., and Engel, L. L. 17-Hydroxypregnenolone as a precursor for cortisol. Fed. Proc. 1961, 20, 179.

7. Mulrow, P. J., and Cohn, G. L. A new pathway of cortisol biosynthesis. Clin. Res. 1961, 9, 186.
8. Carstensen, H., Oertel, G. W., and Eik-Nes, K. B. Secretion of $17 \alpha$-hydroxy-pregnenolone by the canine adrenal gland during stimulation with adrenocorticotropin. J. biol. Chem. 1959, 234, 2570.

9. Bush, I. E. Methods of paper chromatography of steroids applicable to study of steroids in mammalian blood and tissues. Biochem. J. 1952, 50, 370.

10. Eberlein, W. R., and Bongiovanni, A. M. New solvent systems for the resolution of corticosteroids by paper chromatography. Arch. Biochem. 1955, 59, 90.

11. Kliman, B., and Peterson, R. E. Double isotope derivative assay of aldosterone in biological extracts. J. biol. Chem. 1960, 235, 1639.

12. Norymberski, J. K. Determination of urinary corticosteroids. Nature (Lond.) 1952, 170, 1074.

13. Bush, I. E., and Willoughby, M. The excretion of allotetrahydrocortisol in human urine. Biochem. J. 1957, 67, 689.

14. Lipsett, M. B., and Hökfelt, B. Conversion of $17 \alpha$ hydroxypregnenolone to cortisol. Experientia (Basel) 1961, 17, 449.

\section{SPECIAL NOTICE TO SUBSCRIBERS}

Post Offices will no longer forward the Journal when you move.

Please notify The Journal of Clinical Investigation, Business Office, 10 Stoughton Street, Boston 18, Mass., at once when you have a change of address, and do not omit the zone number if there is one. 